2 Horowitz M, Maddox A, Bochner M, et al. Relationships between gastric emptying of solid and caloric liquid meals and alcohol absorption. Am F Physiol 1989;257:G291-8.

3 McFarlane A, Pooley L, Welch I McL, Rumsey RDE, Read NW. How doe dietary lipid lower blood alcohol concentrations? Gut 1986;27:15-8.

4 Finch JE, Kendall MJ, Mitchard $M$. An assessment of gastric emptying by breathalyser. Br f Clin Pharmacol 1974;1:223-6.

5 Cotton PB, Walker G. Ethanol absorption after gastric operations and in the coeliac syndrome. Postgrad Med f 1973;49:27-8.

6 Grimes DS, Goddard J. Effect of cigarette smoking on gastric emptying. BMf 1978;ii:460-1

7 Nowak A, Jonderko K, Kaczor R, Nowak S, Skrzypek D. Cigarette smoking delays gastric emptying of a radiolabelled solid food in healthy smokers. Scand 7 Gastroenterol 1987:22:54-8.

8 Muller-Lissner SA. Bile reflux is increased in cigarette smokers. Gastroenterolog 1986;90:1205-9.

9 Gritz ER, Ippoliti A, Jarvik ME, et al. The effect of nicotine on the delay of gastric emptying. Alimentation, Pharmacology and Therapy 1988;2:173-8.

10 Miller G, Palmer KR, Smith B, Ferrington C, Merrick MV. Smoking delays gastric emptying of solids. Gut 1989;30:50-3.

1 Petring OU, Adelhoj B, Ibsen M, Brynnum J, Poulsen HE. Abstaining from cigarette smoking has no major effect on gastric emptying in habitual smokers. Br f Anaesth 1985;57:1104-6.

12 Chaudhuri TK, Fink S. Effect of nicotine gum on gastric emptying. Chest 1988;94:1122.

13 Collins PJ, Horowitz M, Cook DJ, Harding PE, Shearman DJC. Gastric emptying in normal subjects: a reproducible technique using a singl scintillation camera and computer system. Gut 1983;24:117-25.

14 Cooper JDH. Determination of blood ethanol by gas chromatography. Clin Chim Acta 1971;33:483-5.

Lewis KO. Back calculation of blood alcohol concentration. BMf 1987;295: 800-1.

16 DiPadova C, Worner TM, Julkunen RJK, Leiber CS. Effects of fasting and chronic alcohol consumption on the first-pass metabolism of ethanol. Gastroenterology 1987;92:1169-73.

17 Caballeria J, Baraona E, Rodamilans M, Leiber CS. Effects of cimetidine on gastric alcohol dehydrogenase activity and blood ethanol levels. Gastroenterology 1989;96:388-92.

18 Caballeria J, Frezza M, Hernandez-Munoz R, et al. Gastric origin of the first-pass metabolism of ethanol in humans: effect of gastrectomy. Gastroenterology 1989;97:1205-9.

19 Frezza M, DiPadova C, Pozzato G, Terpin M, Baraona E, Lieber CS. High blood alcohol levels in women; the role of decreased gastric alcohol dehydrogenase activity and first-pass metabolism. $N$ Engl f Med 1990;322: 95-9.

20 Horowitz M, Collins PJ, Shearman DJC. Disorders of gastric emptying and the application of radionuclide methods. Arch Intern Med 1985;145:1467-75. 21 McDonnell WM, Owyang C. Smoking markedly inhibits gastric motility in smokers and nonsmokers [Abstract]. Gastroenterology 1989;96:A332.

22 Carlson GM, Rudden RW, Hug CC, Schmiege SK, Bass P. Analysis of the site of nicotine action on gastric antral and duodenal contractile activity. of nicotine action on gastric antral
J Pharmacol Exp Ther 1970;172:377-83.

23 Valenzuela JE, Defilippi C, Csendes A. Manometric studies on the human pyloric sphincter: effect of cigarette smoking, metoclopramide, and atropine

24 Heddle R, Dent J, Toouli J, Read NW. Topography and measurement of pyloric pressure waves and tone in humans. Am f Physiol 1989;255:G491-7.
. 25 Azpiroz F, Malagelada JR. Intestinal control of gastric tone. Am f Physiol 1985;249:G501-9.

26 Heddle R, Fone D, Dent J, Horowitz M. Stimulation of pyloric motility by intraduodenal dextrose in normal subjects. Gut 1988;29:1349-57.

27 Houghton LA, Read NW, Heddle R, et al. Relationship of the motor activity of the antrum, pylorus and duodenum to gastric emptying of a solid-liquid mixed meal. Gastroenterology 1988;94:1285-91.

28 McCallum RW, Mensch R, Lange R. Definition of the gastric emptying abnormality present in gastroesophageal reflux patients [Abstract]. Gastroenterolgy 1981;80:A1226.

29 Grunberg NE. Nicotine as a psychoactive drug: appetite regulation. Psychopharmacol Bull 1986;22:875-81.

(Accepted 18 September 1990)
Infectious Diseases Unit, Department of Medicine, Royal Postgraduate Medical School, London W12 0HS

Rachanee CheingsongPopov, PHD, senior research officer

Christina Panagiotidi, MSC, technician

Jonathan Weber, MRCP, senior lecturer

Department of Haematology, Royal Postgraduate Medical School, London W12 0HS Stella Bowcock, MRCP, senior registrar

Treloar Haemophilia Centre, Lord Mayor

Treloar College, Hampshire

Anthony Aronstam, FRCPATH, consultant

haematologist

Academic Department of Public Health, St Mary's Hospital Medical School, London W2 1PG

Jane Wadsworth, PHD, senior lecturer

Correspondence to:

Dr J Weber,

Jefferiss Wing, St Mary's

Hospital Medical School

London W2 1NY.

BMf 1991;302:23-6

\title{
Relation between humoral responses to HIV gag and env proteins at seroconversion and clinical outcome of HIV infection
}

\author{
Rachanee Cheingsong-Popov, Christina Panagiotidi, Stella Bowcock, Anthony Aronstam,
} Jane Wadsworth, Jonathan Weber

\section{Abstract}

Objective-To study the contribution of the humoral response to HIV-I at seroconversion to disease outcome after 84 months.

Design-A retrospective longitudinal study.

Setting-Two haemophilia centres in the United Kingdom.

Patients - 88 Haemophiliac patients infected with HIV-I for whom sera were available from before seroconversion and in whom clinical follow up data were available.

Results-Kaplan-Meier survival analysis showed a significant difference between a high titre $(>1600)$ p24 antibody response at seroconversion and prolonged time before the development of HIV related disease $(p=0.0008)$. In contrast, higher titres of antibody to gp120 at seroconversion $(>25600)$ correlated with more rapid clinical deterioration $(\mathbf{p}=\mathbf{0 . 0 2 5})$.

Conclusions - The first humoral response to HIV proteins at seroconversion is associated with clinical outcome; patients with an initial low titre antibody response to the gagp 24 protein have a significantly faster rate of progression to CDC stage IV disease. Patients with a high titre p24 antibody response progress to AIDS more slowly, and these data provide an explanation why p24 antigenaemia is not universally detected in patients with AIDS. It is unclear whether the association between a strong initial p24 antibody response and slower progression of HIV disease is causal and if so whether it is due to viral or host factors.

\section{Introduction}

After infection with HIV-I there is a vigorous humoral response to structural and regulatory viral antigens. ${ }^{1-8}$ Antibodies to the env gene products gp160/gp120 and gp41 are produced early followed shortly by antibodies to the gag gene product $\mathrm{p} 24 . .^{910}$ By studying sequential serum samples from infected patients we and other investigators have found that there is an apparent lowering of titre of p24 (gag) antibodies in patients with more rapid progression to HIV related disease (AIDS related complex and AIDS $)^{11-17}$ whereas no such change is seen with gp41 (env) antibodies.

Subsequently, it has been repeatedly shown that $50-70 \%$ of patients with AIDS have detectable titres of serum p24 antigen whereas only rarely is p24 antigen detectable in asymptomatic patients ${ }^{18-21}$; detection of p24 antigen before symptomatic disease correlated significantly with prognosis over 27 months. ${ }^{19}$ The loss of antibody precedes p24 antigenaemia by 12-18 months, ${ }^{22}$ and this has been interpreted as being due to the formation of immune complexes of p24 antibodies with rising concentrations of p24 antigen. ${ }^{23}{ }^{24} \mathrm{We}$ have recently shown, however, that undetectable titres of p24 antibodies in antigenaemic patients do not rise after the reduction of p24 antigen titre with zidovudine treatment ${ }^{25}$; this suggests that the mechanism for the decline in titre of p24 antibody is unlikely to be the simple formation of immune complexes. Cohort data have shown that over time increasing numbers of patients with preserved high titres of p24 antibody and without detectable titres of p24 antigen develop AIDS, and the association of loss of p24 antibodies with prognosis becomes less significant (unpublished data). ${ }^{25}$ No explanation has yet been offered for these findings or for the failure to detect viral antigens in $30-50 \%$ of patients with AIDS, even when plasma viraemia can be readily detected. ${ }^{26}{ }^{27}$ As the presence of p24 antigen has been used as a surrogate marker of virus replication these data require elucidation

We thus studied the role of the first humoral response to HIV gag, env proteins at seroconversion 
in relation to disease outcome and to provide an explanation for the pattern of p24 (gag) antibody and antigen over time.

\section{Methods}

Patients-Two cohorts of haemophiliac patients from Hammersmith Hospital $(n=19)$ and the Treloar Haemophilia Centre at the Lord Mayor Treloar College $(n=69)$ were studied. All haemophiliac patients attending the centres who had been infected with HIV-I between 1979 and 1985 were included if serial serum samples were available through seroconversion and clinical follow up data were available. Thus 35 patients were excluded because they joined the centres after seroconversion to HIV-I and 17 were lost to follow up. Serial serum samples from eligible patients had been stored at $-20^{\circ} \mathrm{C}$ since venesection. Patients were categorised by the Centers for Disease Control (CDC) clinical classification system ${ }^{28}$ into those who remained asymptomatic (stage II) or with persistent generalised lymphadenopathy alone (stage III) and all those who had progressed to symptomatic disease, AIDS related complex (stages IVa, IVc2, and IVe), and AIDS (stages IVb, IVcl, and IVd). At the time of analysis (October 1989) 22 patients had progressed to stage IV disease, and the remaining 66 had remained in stage II or III.

Serology-Longitudinal serum samples from each patient were initially screened with a direct enzyme linked immunosorbent assay (ELISA) (DuPont); this uses the direct coating of the env9 recombinant envelope protein on the solid phase with antihuman IgG conjugated with alkaline phosphatase as the
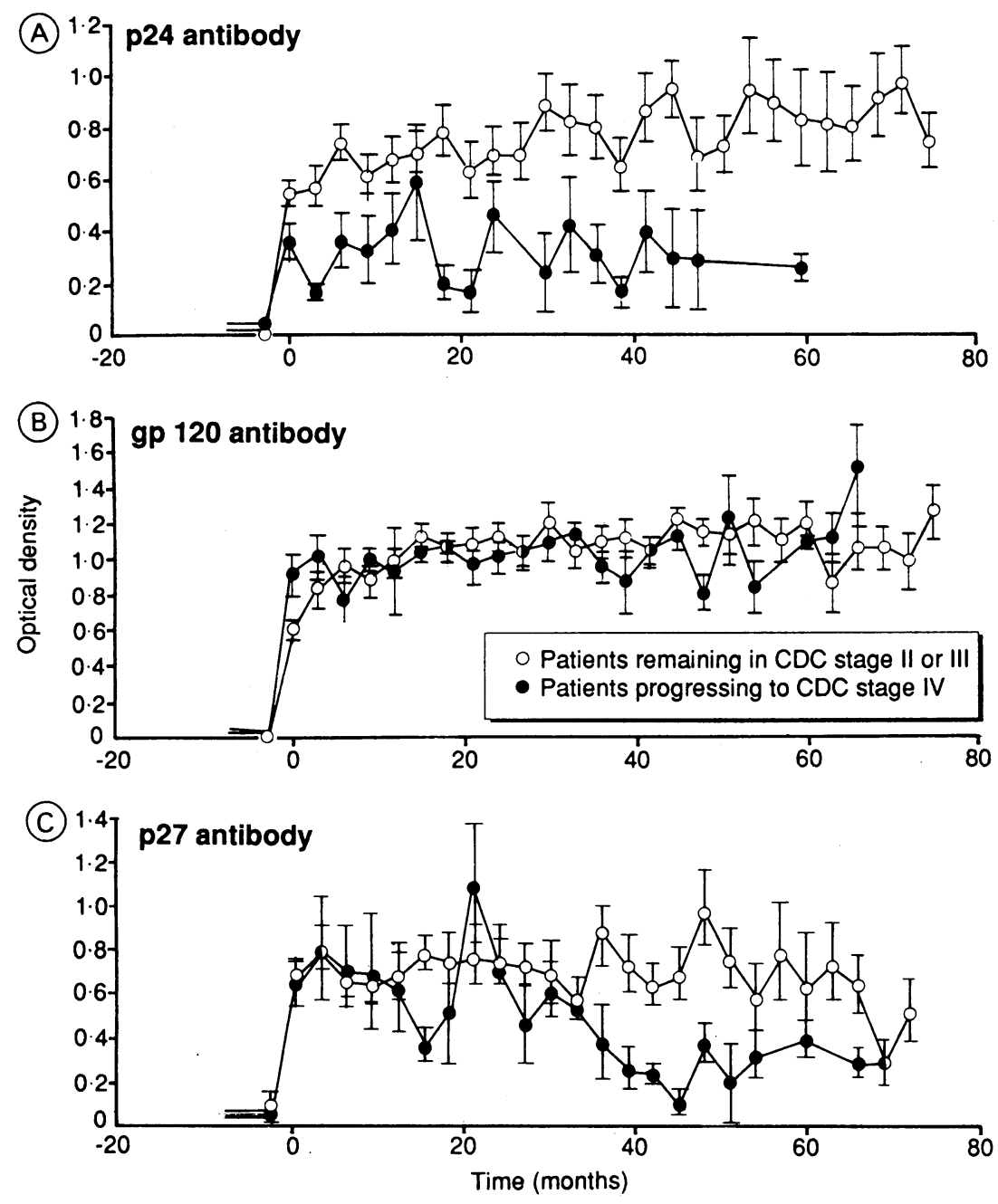

FIG 1-Mean of titres to p24(gag), gp120(env), and p27(nef) antibodies in 88 patients by clinical outcome over the study period. Number of observations: time $0 n=88$; time $30 n=48$; time $60 n=43$. Bars are $S D$ detector. Seroconversion was defined as the first positive serum sample in the assay performed according to the manufacturer's instructions. The samples had been taken at roughly three monthly intervals, and so the date of seroconversion could be ascertained to within 12 weeks in all cases.

Antigens used in quantitative serology on recombinant $H I V$ antigens-Recombinant env(gp120) was a fully glycated CD4 binding protein made in Chinese hamster ovary cells (Celltech) and made available through the AIDS directed programme. The p24 protein was a $b$-galactosidase fusion protein expressed in Escherichia coli and derived from the HIV-I(CBL-1) isolate. The recombinant nef(p27) was expressed in $E$ coli and based on the HIV-I $\mathrm{I}_{(\mathrm{BRU})}$ sequence. The specific direct ELISA immunoassays using these recombinant antigens have been described in detail previously. ${ }^{29}$ The specificity of these assays was first assessed using a panel of $300 \mathrm{HIV}$ negative sera; eight HIV negative control sera were included on each enzyme immunoassay plate and the cut off calculated as the mean optical density at $492 \mathrm{~nm}$ of the negative sera plus three standard deviations. Sera were considered positive if the test optical density was higher than the relative threshold value for that plate.

p24 antigen assay-The commercial p24 antigen assay (DuPont) was used throughout the study according to the manufacturer's instructions.

Statistical analysis - The effect of titre of env(gp120), $\operatorname{gag}(\mathrm{p} 24)$, and nef(p27) antibodies at the first seropositive serum after infection with HIV on the time to progression of members of the cohort to AIDS and AIDS related diseases (stage IV) was assessed by Kaplan-Meier survival analysis. The significance of difference in time to progression from asymptomatic to stage IV disease was tested by the log rank test with $\chi^{2}$ approximation. The significance of differences in titres of the first antibody responses was assessed by the Mann-Whitney U test.

\section{Results}

The pattern of the antibody response to the gag, env, and nef proteins for the whole cohort over the follow up period is shown in figures la-c. Patients who progressed to stage IV disease over this period differed from those who remained asymptomatic in the pattern of p24(gag) antibody titres (fig la) from the first measurement and subsequently but not in p27(nef) antibody titres (fig lc); the gp120(env) antibody titres discriminated only at the first measurement (fig lb). The first positive sera at seroconversion were therefore analysed in greater detail. Figure 2 shows the median and range of the titres of p24(gag), gp120(env), and p27(nef) antibodies for the first positive serum sample after seroconversion from each of the 88 patients in the cohort; values are shown for the 66 patients maintaining stage II or III disease compared with the 22 progressing to stage IV disease. Those maintaining stage II or III disease had a median p24 antibody titre of 1600 and those progressing to stage IV disease had a median of $200(p=0.0008)$. Higher titres of gp120 antibody at seroconversion were associated with progression to stage IV disease (median $=51200$ ) compared with maintaining stage II or III disease (median $=12800, p=0 \cdot 01$ ). In contrast, there was no discrimination in terms of disease outcome in the p27 assays $(p=0 \cdot 13)$. The median values of the antibody titrations were calculated for the sera of the two cohorts together and used as the cut off for the comparison of patients with high and low titre responses in the survival analysis; there was no difference in the time between the last negative and first positive sera in the two groups.

The prevalence of p24 antigenaemia at any time after 
infection was compared with the titre of first antibody response to p24 after infection with HIV. Whereas 6 out of $27(22 \%)$ of the patients with an initial low titre response to p24 had developed p24 antigenaemia only 1 out of $24(4 \%)$ of those with a high titre p24 antibody response developed detectable titres of p24 antigen within 84 months. Antigenaemia developed mainly in patients with an initial low titre antibody response to p24 after HIV infection (Fisher's exact test; $p=0 \cdot 10$ ).

Figure 3a-c shows the relation between time to progression to stage IV disease and high or low titres of the antibody response at seroconversion analysed by Kaplan-Meier survival analysis. Figure $3 a$ shows a significant relation between an initial p24 antibody response and time to progression to stage IV disease; patients with initial titres less than 1600 had significantly shorter times to stage IV disease than those with titres greater than $1600(p=0 \cdot 0008)$. Figure $3 c$ (p27 antibody) shows a similar pattern to $\mathrm{p} 24$ but is less pronounced and is not significant $(p=0 \cdot 128)$. In figure $3 \mathrm{~b}$ patients with titres of gp120 antibody greater than 25600 showed a significantly shorter time to progression to stage IV disease than those with initial titres of gp120 antibodies of less than 25600 $(p=0.025)$. Analysis of the p24 and gp120 antibody titres for the first seropositive serum by regression

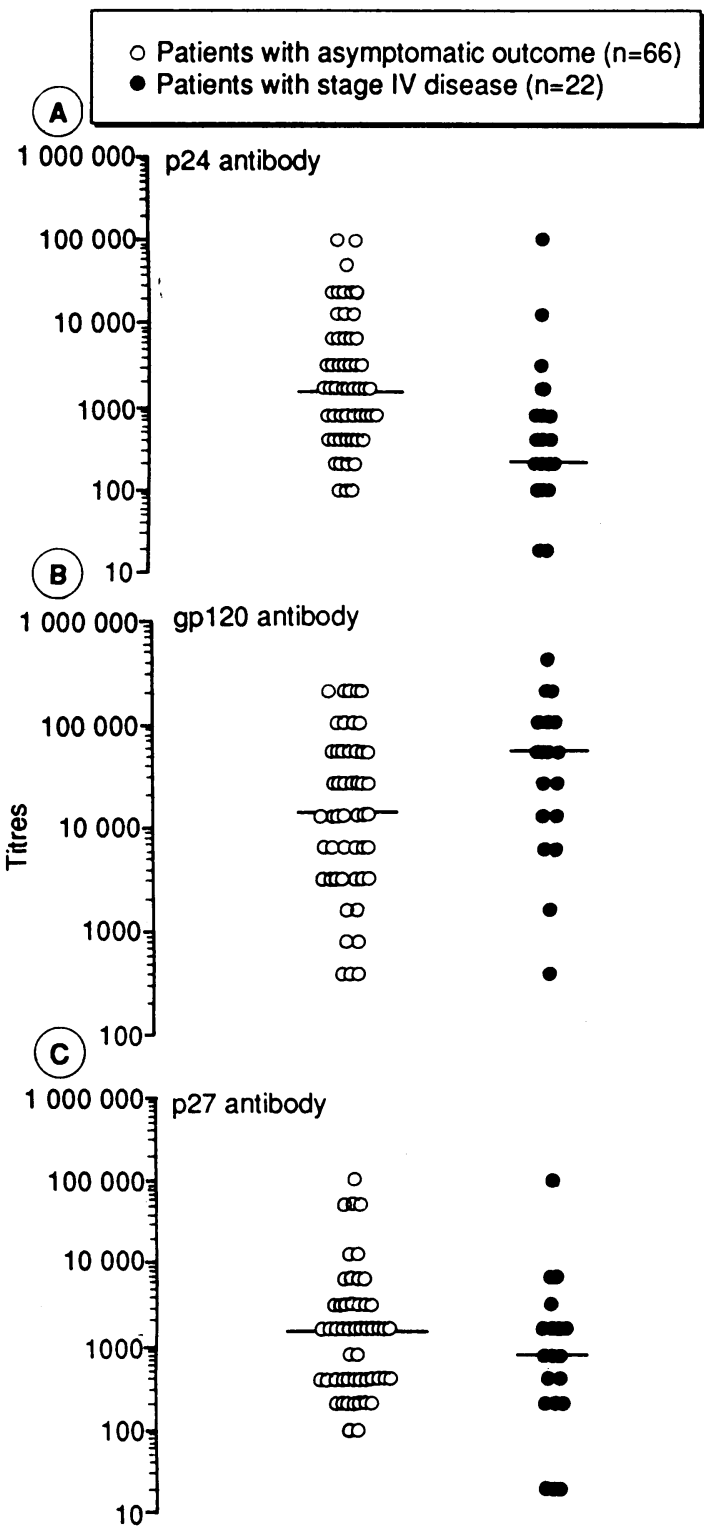

FIG 2-Range of antibody responses to p24(gag), gp120(env), and p27(nef) at the first seropositive sample by clinical outcome over the study period. Bars are median
(A) gag (p24) antibody

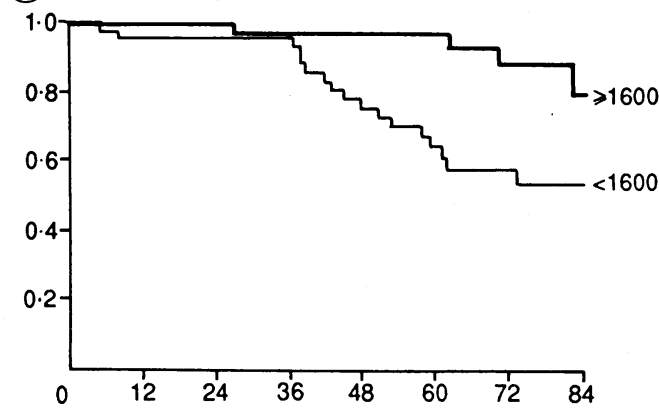

(B) env (gp120) antibody

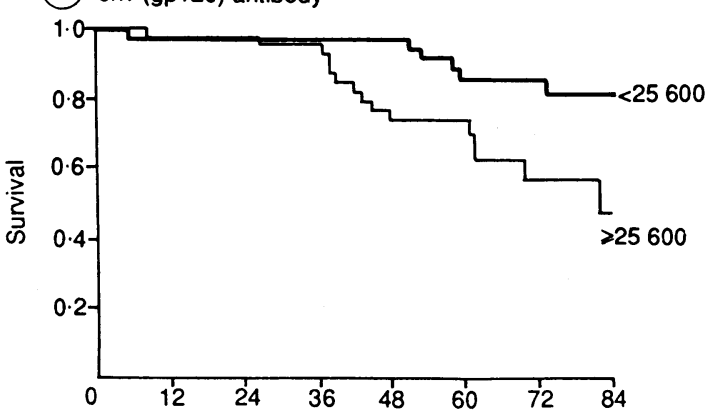

(C) nef (p27) antibody

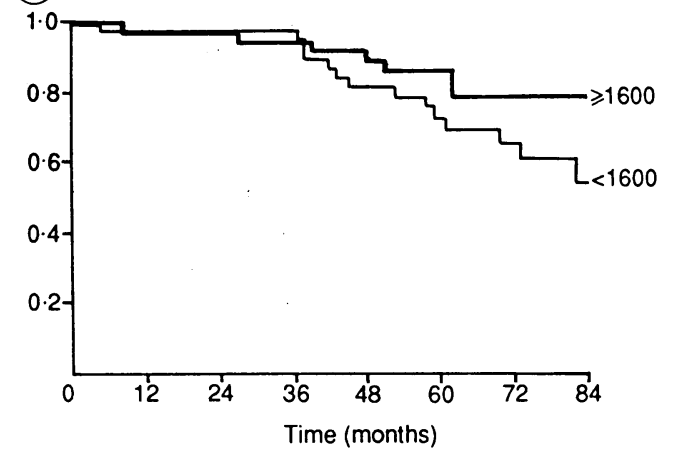

FIG 3-Kaplan-Meier survival analysis by time to progression to stage $I V$ disease in relation to titre of antibody to HIV gag, env, and nef proteins at seroconversion

coefficient showed that these were independent variables (data not shown).

\section{Discussion}

We have shown highly significant associations between p24 and gp120 antibody titres at seroconversion and the time to development of HIV related disease after infection through the parenteral route. Patients with low p24 and high gp120 antibody titres develop HIV related disease more rapidly than do those with high p 24 and low gp120 antibody titres and are more likely to develop p24 antigenaemia; we have also shown that the antibodies to p24 and gp120 are independent variables.

As p24 antigen became detectable in this cohort mainly in the patients with low initial p24 antibody titres it is possible to see how cross sectional studies of HIV infected cohorts have shown conflicting data on the importance of p24 antibody and p24 antigen and why p24 antigenaemia is not universally present in patients with AIDS. Early in the natural history of any cohort low or negative titres of p24 antibodies correlate strongly with the rapid progression of disease. . $^{13-15}$ These patients may become antigenaemic early because the low antibody titre enables antigen detection. ${ }^{30}$ After the death of these patients, however, a higher proportion of the remaining cohort members have persisting high p24 antibody titres, are consequently not detectably antigenaemic, and may develop 
AIDS later without ever becoming antigenaemic.

The observation that higher titres of p24 antibodies are associated with partial protection from disease progression is compatible with previous studies; these have studied longitudinal cohorts, generally where the date of seroconversion is not known. The difference in p24 antibody response from the time of seroconversion suggests that this phenomenon might have biological importance as well as being statistically significant. The association with protection is incomplete, however, as even the patients with a high p24 antibody titre eventually develop stage IV disease (fig 3a). The protection is indirect as there is no evidence that monoclonal p24 antibodies can neutralise HIV in vitro, ${ }^{29}$ although there are reports of possible neutralising antibodies. ${ }^{3132}$ It is impossible to conclude from these data whether the different response to p24 is due to host or viral factors. Possibly, higher quantities of infecting virus might lead to more rapid progression of disease and suppress p24 antibody production. There are several reports of free gp120 binding CD4 receptors and interfering with $\mathrm{T}$ helper cell function and so a high level of circulating virus at seroconversion might depress the cooperation of $\mathrm{T}$ helper cells with $\mathrm{B}$ cells to produce antibody. ${ }^{33-35}$ In addition, the HLA haplotypes of this population were not determined, and there might be an HLA association with p24 antibody response, such as the HLA-A1, B8, DR3 association with HIV outcome already found. ${ }^{36}{ }^{37}$

The association of gp120 antibody with outcome was significant but probably of less biological importance as it was shown at one time point only; after the seroconversion sample gp1 20 antibody failed to predict outcome. Gp120 antibodies, however, might be capable of enhancing HIV infection by $\mathrm{Fc}$ receptor binding mediated by antibody. ${ }^{38} 39$

The mechanism underlying the association of the p24 antibody response with outcome of HIV infection can be answered with confidence only in an animal lentivirus model, such as simian immunodeficiency virus infection in the macaque, where viral and host variables can be controlled. If the association between p24 antibody response at seroconversion and time to disease can be confirmed in macaques then it would be possible to study the value of post exposure immunotherapy with a p24 construct with the aim of delaying the onset of disease by boosting the p 24 antibody response.

The study was funded by the Medical Research Council AIDS directed programme. We thank Dr Gill Hows and Dr David Swirsky for permission to study their patients, and Dr Primrose Watkins and Mr Munaf Ali for technical support. The antigens were kindly supplied by Dr D Parker, Wellcome Diagnostics, Beckenham, and Dr J Le Cocq, Transgene, Strasbourg.

1 Sarngadharan M, Popovic M, Bruch L, Schupbach J, Gallo R. Antibodies reactive with HTLV-III in the serum of patients with AIDS. Science 1984;224:506-8

2 Brun-Vezinet F, Rouzioux C, Barre-Sinoussi F, et al. Detection of IgG antibodies to LAV in patients with AIDS or lymphadenopathy syndrome. Lancet 1984; i: 1253-6.

3 Schupbach J, Popovic M, Gilden R, et al. Serological analysis of a subgroup of HTLV-III associated with AIDS. Science 1984;224:503-5.

4 Cheingsong-Popov R, Weiss RA, Dalgleish A, et al. Prevalence of antibody to HTLV-III in AIDS and AIDS-risk patients in Britain. Lancet 1984;ii: 477-80.
5 Schupbach J, Haller O, Vogt M, et al. Antibodies to HTLV-III in Swiss patients with AIDS and pre-AIDS and in groups at risk of AIDS. N Engl $\mathcal{F}$ Med 1985:312:265-70.

6 Barin F, McLane M, Allain J, et al. Virus envelope protein of HTLV-III represents the major target antigen for antibodies in AIDS patients. Science

7 Ranki A, Krohn $M$, Allain J-P, et al. Long latency precedes overt seroconversion in sexually transmitted HIV infection. Lancet 1987;ii:589-93.

8 Cooper D, Imrie A, Penny R. Antibody response to HIV after primary infection. $\mathcal{Y}$ Infect Dis 1987;155:1113-8.

9 Allain J-P, Laurian Y, Paul D, Senn D. Serological markers in early stages of HIV infection in haemophiliacs. Lancet 1986;ii:1233-6.

10 Gaines H, von Sydow M, Sonnerborg A, et al. Antibody response in primary HIV infection. Lancet 1987; i: 1249-53.

11 Biggar R, Melbye M, Ebbesen P, et al. Variation in HTLV-III antibodies in homosexual men: decline before onset of AIDS. BMF 1985;291:997-8.

12 Steimer K, Puma J, Power M, et al. Differential antibody responses of individuals infected with AIDS-associated retroviruses surveyed using the viral core antigen p25

13 Lange J, Coutinho R, Krone W , al. Distinct IgG relogy 1986; $150: 283-90$. progression of subclinical and clinical infection with LAV/HTLV-III. BMJ
ang progression of sub

14 Lange J, Paul D, Huisman H, et al. Persistent HIV antigenaemia and decline of HIV core antibodies associated with transition to AIDS. BMF 1986;293: 1459-62.

15 Weber J, Clapham P, Weiss R, et al. HIV infection in two cohorts of homosexual men: neutralising sera and association of anti-gag antibodies with prognosis. Lancet 1987; i:119-22.

16 McDougal JS, Kennedy J, Nicholson J, et al. Antibody response to HIV in homosexual men. $\mathcal{F}$ Clin Invest 1987;80:316-24

17 Pan L-Z, Cheng-Mayer C, Levy J. Patterns of antibody response in individuals infected with HIV. F Infect Dis 1987;155:626-70.

18 Pedersen C, Neilsen C, Vestergaard B, et al. Temporal relation of antigenaemia and loss of antibodies to core antigens to development of clinical disease in HIV infection. BMF 1987;295:567-9.

19 de Wolf F, Goudsmit J, Paul D, et al. Risk of AIDS related complex and AIDS in homosexual men with persistent HIV antigenaemia. BMf 1987;295: $569-71$

20 Simmonds P, Lainson F, Cuthbert R, et al. HIV antigen and antibody detection: variable responses to infection in the Edinburgh haemophiliac cohort. BMF 1988;296:593-8.

21 Moss A, Barchetti P, Osmond D, et al. Seropositivity for HIV and the development of AIDS or AIDS-related condition: three year follow up of the San Francisco cohort. BMf 1988;296:745-50.

22 Forster S, Osbourne L, Cheingsong-Popov R, et al. Decline of anti-p24 antibody precedes antigenaemia as correlate of prognosis in HIV-1 infection. AIDS $1987 ; 1: 235-40$.

23 Morrow J, Wharton M, Stricker R, Levy J. Circulating immune complexes in patients with AIDS contain the AIDS-associated retrovirus. Clin Immunol Immunopathol 1986;40:515-24.

24 Lange J, Paul D, de Wolf F, et al. Viral gene expression, antibody production and immune complex formation in HIV infection. AIDS 1987;1:15-21.

25 weber J, Cheingsong-Popov R, Panagiotidi C. Core proteins in the pathogenesis of HIV. In: Groopman J, Essex M, Weiss RA, eds. Human retroviruses. New York: Wiley-Liss, 1989:207-16.

26 Ho D, Moudgil T, Alam M. Quantitation of HIV-1 in the blood of infected persons. N Engl f Med 1989;321:1621-5.

27 Coombs R, Collier A, Allain J-P, et al. Plasma viraemia in HIV infection. $N$ Engl f Med 1989;321:1626-31

28 Centers for Disease Control. Classification system for HTLV-III/LAV associated infections. Ann Intern Med 1986;105:234-7.

29 Cheingsong-Popov R, Panagiotidi C, Ali M, et al. Antibodies to HIVInef(p27): prevalence, significance, and relationship to seroconversion. AIDS Res Hum Retroviruses 1990;6: 1099-105.

30 Tsiquaye $\mathrm{K}$, Youle M, Chanas A. Restriction of sensitivity of HIV-1 antigen ELISA by serum anti-core antibodies. AIDS 1988;2:41-5.

31 Naylor P, Naylor C, Badamchian M, et al. HIV contains an epitope immunoreactive with thymosin alphal and the 30 amino-acid synthetic p17 group-specific antigen peptide HGP-30. Proc Natl Acad Sci USA 1987;84: group-s $2951-5$.

32 Papsidero L, Sheu M, Ruscetti F. HIV-1 neutralising monoclonal antibodies which react with p17 core protein. $\mathcal{F}$ Virol 1989;63:267.

33 Siciliano $\mathrm{R}$, Lawton $\mathrm{T}$, Knall C, et al. Analysis of host-virus interactions in AIDS with anti-gp120 T-cell clones: effect of HIV sequence variation and a mechanism for CD4+ cell depletion. Cell 1988;54:561-75.

34 Mittler R, Hoffman M. Synergism between HIV gp120 and gpl20 specific antibody in blocking human T cell activation. Science 1989;245:1380-2.

35 Manca F, Habeshaw J, Dalgleish A. HIV envelope glycoprotein, antigen specific T-cell responses and soluble CD4. Lancet 1990;335:811-5.

36 Steel CM, Ludlam C, Beatson D, et al. HLA haplotype A1, B8, DR3 as a risk factor for HIV-related disease. Lancet 1988; ;:1185-8.

37 Kaslow R, Duquesnoy R, van Raden M, et al. Al, CW7, B8, DR3 HLA antigen combination associated with rapid decline of $\mathrm{T}$-helper lymphocytes in HIV-1 infection. Lancet 1990;335:927-31

38 Takeda A, Tuazon C, Ennis F. Antibody enhanced infection by HIV-l via Fc receptor-mediated entry. Science 1988;242:580-3.

39 Robinson W, Montefiori D, Mitchell W, et al. Antibody-dependent enhancement of HIV-1 infection in vitro by serum from HIV-1 infected and passively immunised chimpanzees. Proc Natl Acad Sci USA 1989;86: passivel.

(Accepted 17 October 1990) 